\title{
INCENTIVES TO COMPLY WITH COMPETITION LAW
}

\author{
Max Huffman*
}

\begin{abstract}
A ccording to two authors, achieving compliance with competition laws is a question of "incentives to promote compliance and to promote the ethical value of compliance." This Discussion Paper addresses the question of "Incentives to Comply with Competition Laws." It addresses this topic in three steps. First, this Discussion Paper asks about the meaning of "compliance" and considers theoretical questions related to efforts at compliance. Second, this Discussion Paper addresses analytic ambiguity of competition law and other challenges to the achievement of a robust compliance culture. Third, this Discussion Paper asks - as among private enterprises subject to the laws, public overseers enforcing the laws, or individual actors engaged in conduct that implicates the laws whose responsibility is compliance.
\end{abstract}

\section{The Meaning and Theory of Compliance}

Compliance with the law would seem to be a self-defining concept. In ordinary use, "compliance" means keeping within the bounds of the law. The more common use of the term in the competition sphere is more nuanced. The European Commission ("EC") says of compliance:

* Discussion paper compiled by Max Huffman, Professor of Law, Indiana University Robert H. McKinney School of Law. Throughout, the paper draws on ideas discussed by enforcers, non-governmental organizations, private enterprises, and scholars. Keeping with the "soft law" of the Antitrust Marathon the discussion paper limits specific citations to places where a particular statement or idea is drawn directly from a source.

${ }^{1}$ Anne Riley \& Daniel Sokol, Rethinking Compliance, 3 J. ANTITRUST ENF. 31, Draft at 12 (2015), available on SSRN at https://papers.ssrn.com/ abstract_id=2475959. 
In the competition field, it means business proactively respecting competition rules. ("Compliance with competition rules," ec.europa.edu).

Consistent with the EC definition, more than one source defines compliance as a process, to include programs, incentive structures, educational efforts, and cooperation with enforcers. Taken together these minimize the dangers of falling afoul of legal rules and minimize the damage when the law is violated.

Compliance as a process is so firmly developed that the word is rarely used without its being paired with "program" ("compliance program"). The programmatic nature of compliance is a function of three things: (1) the structure of entity decision-making, which seems to suffer a commons problem, (2) agency costs within entities more generally, and (3) the analytically ambiguous nature of competition law.

\section{A. Commons Problems in Entity Decision-making}

A common problem arises when a multiplicity of individual decision makers, seeking to maximize their own welfare, each gain all of the benefit of an individual course of action but bear only part of its cost. Each individual's cost-benefit analysis includes a stronger benefit than cost and each individual takes the course of action. Across the group the total cost is realized and may outweigh the benefit. Cures for the commons problem can include practices that (1) impose the loss on the individual decision-maker or (2) spread the benefit across participants. The effect has been observed in investing behavior during bubbles, in which individuals are rewarded for gains but not punished for losses. ${ }^{2}$

An example in competition compliance may be reports from 2014 of implicit agreements between Japanese auto parts firms and mid-level managers to take the fall for senior executives by pleading guilty and serving jail time - in exchange for which their jobs are held open for them on their release. ${ }^{3}$ If it is the case that true

${ }^{2}$ Cf., e.g., Krisnan Sharma, The relationship between financial sector compensation and excess risk-taking - a consideration of the issues and policy lessons, DESA Working Paper No. 115, at 2 (2012) (describing a "'heads I win' and 'tails you lose'" bonus system"), available at http://www.un.org/esa/desa/papers/2012/wp115_2012.pdf.

${ }^{3}$ See, e.g., Hans Freimel, Japanese executive tells secrets of price fix- 
decision-makers are insulated from risk by mid-level executives who are convinced to bear the loss by offers of future career opportunities, this is a risk allocation decision within the firm that undermines the incentive for the decision maker to comply with the law.

If the commons explanation has explanatory value for corporate compliance, solutions include ensuring decision-makers (1) share the benefits from risky activity, (2) bear an appropriate proportion of its costs, or (3) both.

\section{B. Agency Costs}

The agency cost framework is a more general statement of the problem of individual incentives misaligned from group outcomes. Spencer Waller has discussed the competition law compliance question as a larger one of corporate governance. ${ }^{4}$ This subpart draws primarily on that discussion.

The study of corporate governance begins with the recognition that corporate managers may pursue personal interests at the expense of stakeholder outcomes. The cost to the entity of that divergence is the "agency cost." The field of corporate governance includes the study of ways to reduce agency cost without unduly impacting managers' incentives to engage in productive activity.

Competition policy compliance is a function of managerial decisions within firms and presents the danger of incentives such as rewards for manager entrepreneurialism divorced from goals, including compliance. Nonetheless Waller observed that for much of recent history "the two fields have proceeded without any deep interaction and with little effort to even understand each other's domain."

Antitrust compliance may increase with United States lawmakers' and courts' increased willingness to impose on directors a duty to control managers' inclinations to engage in serious antitrust violations. That duty arises in the context of derivative litigation against the directors alleging a failure to monitor or the lack of a rational business purpose. Such a suit might allege a failure on the board's part to police managerial conduct that led to stock

ing, RubBer News (Nov. 16, 2014), http://www.rubbernews.com/article/20141126/NEWS/141129971/japanese-executive-tells-secrets-of-pricefixing.

${ }^{4}$ Spencer Weber Waller, Corporate Governance and Competition Policy, 18 George MASON UNIV. L. REV. 833, 852-56 (2011). 
price declines due to antitrust liability or its threat. The likelihood of such a suit's proceeding to trial will influence the strength of the board's interest in imposing meaningful compliance obligations on management. Case law informing directors' duties of care is limited and is frequently resolved on the basis of procedural requirements for derivative suits rather than the merits of an antitrust argument.

Outside of the U.S. there are stronger mechanisms enforcing director duties in the context of competition policy. Disqualification statutes in jurisdictions including Canada, the United Kingdom, and Sweden allow (or perhaps require) the remedy for certain convictions. A recent report suggests that a director of a Russian company was penalized for condoning bid rigging by a one-year disqualification. ${ }^{5}$ Several US commentators join Waller in arguing for the adoption of the disqualification remedy in the US. ${ }^{6}$ Evidence of the deterrent effect of this remedy suggests these commentators may be correct. ${ }^{7}$

\section{ANAlytic Ambiguity AND Other ChallengeS}

\section{A. Why is compliance difficult?}

In addition to the institutional impediments discussed in Part I, competition policy raises two problems. The first is the ambiguity of the legal rules and cross-cultural norms of behavior that lead to default conduct that violates the law. The second is the size of the incentives for noncompliance - the gains from violating the law. The compliance challenge arises in overcoming these impediments as well.

5 "An official is disqualified for participating in a cartel," June 2, 2017 News Release, Federal Antimonopoly Service of the Russian Federation, available at http://en.fas.gov.ru/press-center/news/detail.html?id=50339 (visited February 8, 2018).

${ }^{6}$ See, e.g., Douglas H. Ginsburg \& Joshua D. Wright, Antitrust Sanctions, 6:2 COMP. POL'Y INT'L 19 (2010).

${ }^{7}$ UN Conference on Trade and Development, "Strengthening private sector capacities for competition compliance," at 4 (2016) ("companies considered director disqualification and adverse publicity as more important drivers to compliance than fines," discussing 2007 study by UK Office of Fair Trading and Deloitte and Touche), available at http://unctad.org/meetings/en/SessionalDocuments/ciclpd39 en.pdf (visited February 8, 2018). 
According to the International Chamber of Commerce's "Antitrust Compliance Toolkit":

Existing antitrust laws are constantly evolving and new laws are being adopted. Sanctions for antitrust violations are often substantial and reputational damage to companies as a result of an adverse antitrust finding is massive. (ICC 2013).

\section{B. Ambiguous Legal Rules}

Ambiguous legal rules may present a particular compliance problem. Stated simply, a rule that says "thou shalt not kill" is much easier to follow than is a rule that says, "don't be evil."

The concern for ambiguity arises when the compliance challenge relates to other than cartel activity. The core cartel prohibitions - price fixing and bid rigging conspiracies - carry criminal penalties in the US and an increasing number of non-US jurisdictions and are easily distinguishable from non-cartel conduct. Partly based on this lack of ambiguity, argued that the duty of care for directors should be heightened for this sort of conduct. ${ }^{8}$

Other rules are less clear. Even horizontal agreements like market allocations that continue to be treated to per se prohibition in the US and comparable summary prohibition in the European Union and other jurisdictions are less than perfectly clear in their identification. For example, former FTC Chair Jon Liebowitz once characterized pharmaceutical reverse-payment settlements as naked market allocation agreements; the US Supreme Court has held that those agreements should be treated under the Rule of Reason. ${ }^{9}$ Even prior to that ruling, there were no examples of criminal prosecutions of reverse payment agreements.

Similarly, vertical agreements on price, which categorically shifted to Rule of Reason treatment in the U.S. a decade ago, ${ }^{10}$ are treated with greater suspicion in the EU and its members, including the recent fine the UK Competition and Markets Authority imposed on National Lighting Company and the simultaneous "open letter to suppliers and resellers" about Resale Price Maintenance. ${ }^{11}$

${ }^{8}$ Waller, supra note 4 , at 859-68.

${ }^{9}$ See FTC v. Actavis, 570 U.S. 136, 159 (2013).

${ }^{10}$ Leegin Creative Leather Prods., Inc. v. PSKS, Inc., 551 U.S. 877, 899 (2007).

${ }^{11}$ Ann Pope, "Restricting resale prices: an open letter to suppliers and 
The further antitrust prohibitions get from cartels, the greater the ambiguity: unilateral conduct and mergers present difficult and politically salient enforcement challenges. Counseling on these forms of conduct is as likely to involve analyzing the politics of competition agency leadership as it is to involve interpretation of legal authorities. Similarly, seemingly every jurisdiction is subject to criticisms of enforcement based on the protection of "national champions" overriding concerns for competitive markets.

New and developing competition policies often seem to pick between the US and the EU rules, resulting in a patchwork of regulation. The result is that a cross-border business can do one of three things: (1) comply with the most stringent regulation, (2) invest in sophisticated counseling to comply with rules in every jurisdiction, or (3) risk prosecution for violations.

\section{Achieving Negative Expected Value}

Large incentives to violate the law necessitate punitive measures to prevent law violation, in order to produce an expected value calculus that is negative for the would-be lawbreaker. Punitive measures include public prosecution with punishment encompassing fines, incarceration, and debarment. Punitive measures also include private prosecution with punishment in the form of damages multipliers. The purpose of punishment is of course to deter law-breaking. ${ }^{12}$ Evidence suggests that it succeeds in doing so: "Fines that are set at the appropriate level do have a deterrent effect as discussions with our stakeholders clearly show."13

There are disputes among academics regarding the effectiveness of deterrence through fines or other sanctions. Some arguments suggest current sanctions are insufficient when combined

resellers," COMPETITION \& MARKETS AUthoRITy (June 20, 2017), available at https://www.gov.uk/government/uploads/system/uploads/attachment_data/file/620454/resale-price-maintenance-open-letter.pdf.

${ }^{12}$ William H. Page, Optimal Antitrust Remedies: A Synthesis, in 1 OXFord HANDBOOK OF INTERNATIONAL ANTITRUST ECONOMICS $\mathrm{Ch}$. 11 (Roger D. Blair \& D. Daniel Sokol, eds. 2014).

${ }_{13}$ Joaquín Alumnia, "Compliance and Competition Policy," Address to Businesseurope and the U.S. Chamber of Commerce Competition Conference (Oct. 25, 2010), available at europa.eu/rapid/press-release_SPEECH-10-586_en.pdf. 
with the likelihood of discovery. ${ }^{14}$ The same argument is commonly made with regard to cartel enforcement in the EU. ${ }^{15}$

Other arguments suggest sanctions are irrationally applied, at least in the US system, which gives the theoretical possibility of both public prosecution and private treble damages sanctions for the same conduct, as well as treble damages for conduct with ambiguous competitive consequences and illegality. ${ }^{16}$

Perhaps consistent with the irrationality hypothesis, sources note the diversity of legal or extra-legal sanctions for competition law violations. These may include "financial penalties, unenforceability of agreements, administrative and advisory costs, injunctions, third-party damages actions, adverse publicity, director disqualification and, in certain cases, imprisonment." The effect of this multiplicity of sources of costs imposed on law-breakers is itself ambiguous. It may either undermine ("who knows what may happen so why be concerned!") or strengthen ("look at all the pitfalls - better avoid this!") the incentives for compliance.

The size of punishment for a violation is only the first half of the expected value calculus. The degree of punishment required to achieve negative expected value calculus also turns on (1) the likelihood of discovery and (2) the likelihood of successful prosecution after discovery.

Likelihood of discovery of violations is enhanced with increased resources devoted to competition policy enforcement and belts-and-suspenders (dual, tripartite) enforcement structures. Dual public enforcement, such as treaty-level and state-level (EU) or federal-and state-level(US), mitigates the concern for politically powerful violators escaping sanction. Private enforcement may offer a bounty to ensure enforcement resources flow to areas of likely success and can backstop public enforcement when for political or budgetary reasons the level of enforcement is insufficient.

${ }^{14}$ See John M. Connor \& Robert H. Lande, Cartels as Rational Business Strategy: Crime Pays, 34 Cardozo L. REv. 427 (2012).

${ }_{15}$ See Florence Thépot, Can Compliance Programmes Contribute to Effective Antitrust Enforcement?, in Competition Law Compliance Programs: An Interdisciplinary Approach 191, 194-95 (Johannes Paha, ed., 2016).

${ }^{16}$ See William H. Page, Optimal Antitrust Remedies: A Synthesis, in 1 Oxford Handbook of International Antitrust Economics (Roger D. Blair \& Daniel Sokol, eds. 2014).

17 "Strengthening private sector capacities," supra note 7, at 2-3. 
Likelihood of successful prosecution is a more nuanced question. Successful prosecution requires prosecutors and courts to be in sync with regard to the meaning of rules being enforced. The likelihood of such syncing seems to turn on the degree of remove between the various actors. An agency that combines investigation, prosecution, and adjudication, might be expected to realize the greatest alignment among the three. Consistent with this, a recent study finds no instances from 2006-2016 of the Commission's rejecting "an action that it had previously authorized complaint counsel to bring," although deeper investigation into the empirics demonstrates the results are not so lop-sided as that simple statistic suggests. ${ }^{18}$

An agency that is independent of the courts is less likely to reflect the same alignment because courts are not involved in the decision to investigate or to bring an action. This is the case although both courts and prosecutors serve the same fundamentally public mission. Private enforcement is least likely to reflect the alignment between decision to sue and ultimate liability, because by its nature private enforcement serves a profit motive rather than a public mission.

\section{PUblic, PRIVATE, OR INDIVIDUAL?}

This part raises the question where primary responsibility for compliance should reside - with public entities, usually enforcement agencies; with private firms, subject to their regulation; or with the individual who is actually charged with decisions that may violate the law.

\section{A. Public Imposition of a Compliance Regime}

Enforcement agencies frequently see part of their role to assist firms in keeping in compliance with the law through a diverse array of contributions. According to former EC Commissioner Joaquín Alumnia, "The ultimate aim of our cartels and antitrust policies is not to levy fines - the objective is to have no need for fines at all." 19

${ }^{18}$ Maureen K. Ohlhausen, Administrative Litigation at the FTC: Effective Tool for Developing the Law or Rubber Stamp?, 12 J. CoMP. L. \& ECON. 623, 623, 628-35 (2016).

${ }^{19}$ Joaqín Alumnia, "Compliance and Competition Policy," Speech at 
These public efforts include education programs, business review and pre-merger review processes, and prosecutorial incentives for compliance programs. Of these, the first two operate to reduce the cost of compliance while the third speaks to incentives to comply (a fourth public effort is the leniency procedure in place in all developed competition policy systems. That is a topic for the second half of Antitrust Marathon VI and is left unexplored here). The subpart addresses education programs and business review, leaving prosecutorial incentives for the next subpart.

\section{B. Education Programs}

Education programs are themselves a diverse array of public-facing communications by agencies. Enforcers at both political and staff levels are regular participants in professional meetings and academic colloquia. Enforcement agencies in all of the developed competition systems have well-designed and comprehensive internet websites which include speeches, reports, guidelines, and court filings. The European Commission's collection of annual reports, newsletters, reports and studies, and brochures and factsheets -- many published in all of the EU languages -- is likely the most comprehensive and accessible example. Education programs incentivize compliance by reducing the barriers to it.

\section{Business Review}

Business review processes and pre-merger review mitigate the challenges facing firms from ambiguous prohibitions. Both US enforcement agencies have a business review procedure outlined in the Code of Federal Regulations. According to the Antitrust Division's website:

The Antitrust Division's business review procedure provides a way for businesses to determine how the Division may respond to proposed joint ventures or other business conduct. (DOJ Antitrust 2011).

the Businesseurope \& U.S. Chamber of Commerce Competition Conference, Oct. 25, 2010, transcript avail. at europa.eu/rapid/press-release_SPEECH-10-586_en.doc (last visited Feb. 8, 2018). 
The FTC's comparable "Advisory Opinion" process offers two levels of formality - staff opinions and Commission opinions. ${ }^{20}$ Notably, the use of business reviews targets the most ambiguous forms of firm conduct including joint ventures.

Pre-merger review, the dominant approach to merger control in all developed competition law systems, is another approach to public imposition of compliance regimes. Before any liability might attach to an anticompetitive merger the enforcement agency has the opportunity to review and to test the merger in court. Premerger review is a half-solution in a jurisdiction with private remedies, but examples of private damages for an anticompetitive merger that has not been challenged are rare to non-existent.

\section{Private Adoption of a Compliance Program}

Private firms, acting through individual decision-makers within those firms, are the ultimate lawbreakers when laws are broken. As argued above with regard to collective action problems and agency costs, firms are also the best able to adopt systems to prevent law-breaking.

Studies suggest private compliance programs can be effective because of their signaling value both within and outside of the firm. Outside the firm the signal is one of responsibility and respect for law. A cynic might see that signal as consistent with compliance as a cosmetic effort. Inside the firm the signal may be more valuable, supporting a top-down culture of compliance that affected individual managers' decisions. ${ }^{21}$ Put simply, devoting resources to a compliance program signals to employees that management and the board of directors value compliance.

Compliance programs adopted by firms are common, frequently sophisticated, and informed by public education programs and private legal counsel. Good reason exists to believe these programs may be the best defense against firms' violating competition laws. The opposite view is that the sophistication relates primarily to successful regulatory arbitrage.

${ }^{20}$ FTC Bureau of Competition, "Guidance from the Bureau of Competition on Requesting and Obtaining an Advisory Opinion," at 1-2, available at https://www.ftc.gov/system/files/attachments/competition-advisory-opinions/advisoryopinionguidance-

bctextjune2011 update links oct 2015.pdf (visited February 8, 2018).

${ }^{21}$ See "Strengthening private sector capacities," supra note 7, at 6-7. 


\section{E. Incentives for Private Compliance Programs}

One question frequently debated is whether a compliance program should be a basis for reduced punitive liability when the program does not prevent a particular instance of law-breaking. One view is that it should not:

To those who ask us to lower our fines where companies have a compliance programme, I say this: if we are discussing a fine, then you have been involved in a cartel; why should I reward a compliance programme that has failed? The benefit of a compliance programme is that your company reduces the risk that it is involved in a cartel in the first place. That is where you earn your reward. (Alumnia 2010).

This approach characterizes the two dominant competition law systems, although in the US there is room for fine reductions during criminal sentencing and some evidence of recent consideration of compliance programs in plea agreements. ${ }^{22}$

The opposite view holds that the fact of a compliance program may itself be an outcome to be sought, favoring its reward. The argument is that compliance programs are a component of a deterrence regime and socially optimal deterrence demands incentives for compliance as well. Citing the example of Chile's competition system:

[T] hese antitrust authorities arguably provide greater incentive for proactive change for those companies that otherwise may not have sufficient incentive or motivation to invest in a robust compliance problem - and perhaps importantly continue to encourage companies to invest in compliance (even where they are already minded to do so), given the "competition for resources" between different compliance requirements within a company across substantive areas of law and regulation. (Riley \& Sokol 2014).

This approach may be gaining currency, with the UK's Competition and Markets Authority and Italy's Antitrust Authority both offering discounts on fines in the presence of compliance

${ }^{22}$ See Thépot, Compliance Programmes, supra note 15. 
programs. ${ }^{23}$ The credit approach is consistent with those followed for anti-corruption enforcement in many jurisdictions. ${ }^{24}$

Which approach one favors may also turn on one's view of the optimality of the current punitive regime in combination with investigation and prosecution capabilities. As the discussion paper notes above, it may be theoretically possible to achieve optimal deterrence by increasing the expected cost of violations. Adding a break for a compliance program into the calculus increases the incentive. It also complicates the calculus.

\section{F. Cosmetic Compliance?}

Sokol uses the phrase "cosmetic compliance" to refer to programs that meet requirements for prosecutorial incentives but do not meaningfully impact corporate culture. Sokol goes further and notes concerns that a compliance program "may end up being a way for lawyers to make money and for companies to identify and stop whistle-blowers before they get to the authorities."25

Sokol observes a subspecies of the larger phenomenon of regulatory arbitrage, whereby regulated entities exploit gaps in regulation to their advantage. ${ }^{26}$ Examples of arbitrage exist in every form of regulated activity in the economy and its cure is either the elimination of regulation or doubling down on regulation.

Sokol's conclusion is that "DOJ needs a better system to determine when the output (criminality) is a function of bad inputs (e.g., poor compliance program) as opposed to an aberration of a 'bad apple' of an otherwise a well-implemented compliance program." His suggestions include greater emphasis on the individual actor within the firm rather than fines and private remedies imposed on the firm itself:

\section{G. Individual Decisions to Comply}

Individuals might be hoped to comply with competition policy requirements as a matter of public spiritedness or morality.

${ }^{23}$ See Thépot, Complaince Programmes, supra note 15.

${ }^{24}$ See Riley \& Sokol, Rethinking Compliance, supra note 1, at 22-23.

${ }^{25}$ Daniel Sokol, Cartels, Corporate Compliance, and What Practitioners Really Think About Enforcement, 78 ANTITRUST L.J. 201, 233, 233-34 (2012).

${ }^{26}$ See Victor Fleischer, Regulatory Arbitrage, 89 TEx. L. REv. 227, 229 (2010). 
Even at best, such a hope assumes the competition policy deals with activities that are malum in se, which is the case for cartel behavior but less likely for other concerted conduct, unilateral conduct, and mergers.

Assuming instead the need for legal consequences for violations, placing the compliance obligation on individuals also assumes they bear the cost of their conduct. This Discussion Paper notes above ${ }^{27}$ the likelihood that the cost is spread across the firm, perhaps allocated by intra-firm decisions to an underling (as is said to occur the case of mid-level executives in Japanese firms). When the individual realizes the benefits of conduct but does not bear its costs, the individual's incentives to comply are warped.

If, instead, institutional rules place the full cost of non-compliance on the decision-maker, or reduce the benefits from entrepreneurship that may cross legal lines, this would shift to the individual the incentive to ensure compliance. This approach is consistent with the conclusions that as an empirical matter firms do not respond adequately to the penalties-whether fines or punitive damages. It is also consistent with the theoretical predictions in Part I about individual disincentives based on commons and agency costs analyses.

${ }^{27}$ See supra Part I. 